\title{
Pengaruh Kualitas Produk dan Kepercayaan Merek Terhadap Minat Beli Produk Lipstik Wardah di Kecamatan Buleleng
}

\author{
I Gusti Ayu Dyani Puspita Dewi ${ }^{* 1}$, Ni Nyoman Yulianthini² \\ 1,2Program Studi Manajemen \\ Universitas Pendidikan Ganesha \\ Singaraja, Indonesia
}

\section{e-mail: dyanipuspita24@gmail.com¹ , nyoman.yulianthini@undiksha.ac.id ${ }^{2}$}

\footnotetext{
Pengutipan:

Dewi, I. G.A.D.P. \& Yulianthini, N. N. (2021).

Pengaruh

Kualitas Produk

Dan Kepercayaan

Merek Terhadap

Minat Beli Produk

Lipstik Wardah Di

Kecamatan

BulelengJurnal

Pendidikan

Ekonomi

Undiksha, 13 (1),

178-186

http://dx.doi.org/1 $0.23887 /$ ijpe.v13i $\underline{1.32275}$
}

\begin{abstract}
Abstrak
Riwayat Artikel Tanggal diajukan: 16 Februari 2021

Tanggal diterima : 17 Mei 2021

Tanggal dipublikasikan: 25 Juni 2021

Penelitian ini bertujuan untuk menguji pengaruh dari kualitas produk dan kepercayaan merek baik secara simultan maupun parsial terhadap minat beli produk Lipstik Wardah di Kecamatan Buleleng. Rancangan penelitian yang digunakan adalah penelitian kuantitatif kausal. Penentuan sampel dalam penelitian menggunakan teknik purposive sampling. Jumlah sampel yang digunakan adalah 100 responden. Instrumen yang digunakan dalam pengumpulan data adalah kuesioner dan teknik analisis data yang digunakan adalah analisis regresi linier berganda. Hasil dari penelitian ini adalah: (1) Kualitas produk dan kepercayaan merek berpengaruh signifikan terhadap minat beli produk Lipstik Wardah. (2) Kualitas produk berpengaruh positif dan signifikan terhadap minat beli produk Lipstik Wardah. (3) Kepercayaan merek berpengaruh positif dan signifikan terhadap minat beli produk Lipstik Wardah.
\end{abstract}

Kata Kunci: kepercayaan merek; kualitas produk; minat beli.

\begin{abstract}
This study aimed to examine the influence of product quality and brand trust both simultaneously and partially on the buying interest in Wardah Lipstick products in Buleleng District. The research design used was causal quantitative research. Determination of the sample in this study used purposive sampling technique. The number of samples used was 100 respondents. The instrument used in data collection was a questionnaire and the data analysis technique used was multiple linear regression analysis. The results of this study are: (1) Product quality and brand trust have a significant effect on buying interest in Wardah Lipstick products. (2) Product quality has a positive and significant effect on buying interest in Wardah Lipstick products. (3) Brand trust has a positive and significant effect on buying interest in Wardah Lipstick products.
\end{abstract}

Keywords : brand trust; buying interest; product quality.

\section{PENDAHULUAN}

Ketatnya tingkat persaingan di dunia industri perawatan diri dan kosmetik, membuat perusahaan mencari cara untuk tetap menunjukkan eksistensinya dan berusaha dengan maksimal untuk dapat menaikkan tingkat penjualan. Produk kosmetik merupakan produk yang cukup potensial di Indonesia, telah sebesar $63,90 \%$ produk diregistrasikan di Badan Pengawas Obat dan Makanan, ini merupakan persentase tertinggi dibandingkan komoditas lain seperti makanan dan minuman, obat-obatan serta suplemen makanan (BPOM, 2019). Sejalan dengan pertumbuhan kelas menengah dan konsumen yang semakin makmur, sektor kosmetik di Indonesia memiliki kinerja yang kuat dan mampu berada di atas pertumbuhan ekonomi nasional, pada tahun 2017 tumbuh mencapai $6,35 \%$ dan naik menjadi $7,36 \%$ di triwulan 1/2018 (Sigit, 2018). 
Kosmetik dikalangan wanita, terutama remaja perempuan merupakan salah satu bagian dari gaya hidup sering kali mereka selalu mengikuti trend gaya make up dan jenis produk make up yang sedang populer dengan tujuan mendapatkan penampilan yang sempurna. Adanya penerapan regulasi halal kosmetik di Indonesia memberi pengaruh pada meningkatnya penjualan kosmetik halal di Tanah, dan Wardah termasuk produsen kosmetik halal pertama di Indonesia yang berhasil memanfaatkan trend ini dan menjadi brand kosmetik terkemuka di Indonesia (GBGI, 2018). Wardah telah ada sejak tahun 1995 yang berasal dari bisnis rumahan kecil namun telah berkembang menjadi perusahaan multinasional yaitu PT Paragon yang memiliki anak perusahaan Wardah, Make Over, dan Emina (Bastian, 2019).

Wardah juga merupakan salah satu brand kosmetik yang masuk dalam Top Brand Award tahun 2017 sampai dengan tahun 2020, khususnya pada produk lipstiknya yang memiliki persentase tertinggi sebesar $128,1 \%$ dibanding produk Wardah lainnya. Dapat diketahui bahwa Lipstik merek Wardah berada di peringkat pertama dengan predikat TOP dalam empat tahun terakhir. Pada tahun 2018 mengalami peningkatan persentase sebesar $11,2 \%$ namun mengalami penurunan pada tahun 2019 sebesar 2,8\% dan kembali terjadi kenaikan hanya sebesar $0,1 \%$ di tahun 2020. Berbeda dengan produk pesaing yakni Revlon yang berada diperingkat kedua yang mengalami penurunan persentase dari tahun 2017 sampai dengan tahun 2020, sedangkan brand lipstik yang berada diposisi ketiga yaitu Viva yang memiliki presentase terendah.

Posisi Top Brand kosmetik Wardah mengidentifikasi bahwa minat beli konsumen pada Lipstik Wardah mengalami fluktuasi, ini menunjukkan adanya konsumen yang melakukan perpindahan ke merek pesaing atau adanya ketidakpuasan pada produk yang digunakan. Menurut Pramuda \& Hafizha (2010) menyatakan bahwa adanya berbagai macam produk dengan berbagai variasi jenis merek, maka akan mempengaruhi konsumen untuk mencoba-coba dengan berbagai macam produk dan merek sehingga konsumen tidak akan sepenuhnya setia akan suatu produk. Oleh sebab itu perlu untuk mengetahui variabel-variabel yang mempengaruhi minat beli Lipstik Wardah. Menurut (Iwan Dkk (2019), minat beli merupakan kecendrungan konsumen untuk membeli suatu merek atau melakukan hal yang berhubungan dengan pembelian yang diukur dengan tingkat kemungkinan konsumen melakukan pembelian. Minat beli dapat memberikan motivasi yang kuat dalam diri konsumen hingga mereka akan mengaktualisasikan apa yang ada di dalam benaknya tersebut (Afianka, 2012).

Minat beli konsumen dapat dipengaruhi oleh iklan, kepercayaan merek, dan kualitas produk, (Mulyadi Dkk (2015). Panglipurningrum et al. (2018), menyatakan bahwa minat beli konsumen dapat dipengaruhi oleh kualitas produk, harga, brand Image, dan brand trust. Tria, Dkk (2018), menyatakan bahwa minat beli dipengaruhi oleh kesadaran merek, kepercayaan merek dan keunggulan produk. Wirayanthy \& Singgih (2019) menyatakan bahwa minat beli dapat dipengaruhi oleh harga, citra merek dan kualitas. Deniel, Dkk (2018), menyatakan bahwa minat beli dipengaruhi oleh kualitas produk dan eWOM. Hulu \& Ruswanti (2018), menyatakan bahwa minat beli dapat dipengaruhi oleh promosi dan kepercayaan konsumen. Hudzaifah (2018), menyatakan bahwa minat beli dapat dipengaruhi oleh kualitas produk, kepercayaan merek dan kepuasan konsumen. Valentine \& Agus (2019), menyatakan bahwa minat beli dipengaruhi oleh citra merek dan kualitas produk. Jadi dapat disimpulkan faktor-faktor yang mempengaruhi minat beli yaitu iklan, kepercayaan merek, kualitas produk, harga, citra merek, kesadaran merek, keunggulan produk, eWOM, dan promosi. Dalam penelitian ini hanya memfokuskan pada variabel kualitas produk dan kepercayaan merek. Karena variabel kualitas produk berpengaruh dominan pada penelitian Valentine \& Agus (2019) dan kepercayaan merek juga berpengaruh dominan pada penelitian (Mulyadi, Dkk, 2015).

Kualitas produk merupakan variabel yang mempengaruhi konsumen dalam membeli suatu produk. Menurut Candra et al. (2014), menyatakan apabila suatu produk 
memiliki kualitas yang bagus dan sesuai dengan harapan konsumen maka akan meningkatkan minat beli konsumen terhadap produk tersebut. Hal tersebut juga sejalan dengan penelitian yang dilakukan oleh Citra \& Suryono (2016), yang menyatakan bahwa dengan adanya produk yang memiliki keunggulan dibandingkan produk lain maka akan meningkatkan kemungkinan konsumen untuk melakukan pembelian terhadap produk tersebut terlebih lagi produk tersebut sesuai dengan yang diharapkan konsumen dan dapat memenuhi kebutuhan yang diinginkan oleh konsumen. Penelitian tersebut juga sejalan dengan penelitian yang dilakukan Wirayanthy \& Singgih (2019), yang menyatakan bahwa terdapat pengaruh positif variabel kualitas produk terhadap minat beli. Namun berbeda dengan hasil penelitian yang dilakukan oleh Alkutubi \& Muhammad (2019), menyatakan bahwa variabel kualitas produk tidak berpengaruh positif terhadap minat beli.

Selain kualitas produk, kepercayaan merek juga merupakan variabel yang mempengaruhi minat beli pada suatu produk. Menurut Fandiyanto et al. (2019), untuk menciptakan dan mempertahankan konsumen yaitu dengan dengan membentuk dan menjaga kepercayaan konsumen, sehingga kepercayaan dapat menjadi pondasi dalam sebuah bisnis. Merek adalah produk atau jasa penambah dimensi yang dengan cara tertentu dapat mendiferensiasikan merek tersebut dari produk atau jasa lain yang dirancang untuk memuaskan kebutuhan yang sama (Philip Kotler \& Keller, 2016). Sehingga kepercayaan merek diartikan sebagai suatu perasaan dimana konsumen merasa aman terhadap merek sebagai akibat dari interaksinya terhadap merek tersebut yang didasarkan pada persepsi bahwa merek itu dapat diandalkan dan dapat bertanggung jawab atas kepentingan dari konsumen (Philius et al., 2015). Hal tersebut juga sejalan dengan penelitian yang dilakukan oleh Tria, Dkk (2018), yang menyatakan bahwa kepercayaan merek memiliki pengaruh signifikan terhadap minat beli konsumen. Namun hasil penelitian tersebut berbeda dengan Bagus (2015), yang menyatakan bahwa kepercayaan merek berpengaruh tidak signifikan terhadap minat beli. Hasil penelitian yang dilakukan oleh Permata, dkk (2014), menyatakan bahwa tidak terdapat pengaruh positif signifikan kepercayaan merek terhadap minat beli.

Kecamatan Buleleng merupakan salah satu kecamatan di Kabupaten Buleleng dengan proyeksi penduduk perempuannya mencapai $70,14 \%$, dan ini merupakan proyeksi tertinggi dibandingkan dengan delapan kecamatan yang terdapat di Kabupaten Buleleng (BPS, 2020). Hal ini sejalan dengan potensi industri kosmetik dimana mayoritas targetnya adalah konsumen perempuan.

Berdasarkan pemaparan tersebut, diduga terdapat pengaruh antara kualitas produk dan kepercayaan merek terhadap minat beli. Sehingga dalam penelitian ini, tertarik untuk menguji kembali mengenai "Pengaruh Kualitas Produk dan Kepercayaan Merek terhadap Minat Beli Produk Lipstik Wardah di Kecamatan Buleleng".

Berdasarkan latar belakang dan rumusan masalah penelitian, maka tujuan yang ingin dicapai dalam penelitian ini adalah sebagai berikut. (1) Menguji pengaruh kualitas produk dan kepercayaan merek terhadap minat beli produk Lipstik Wardah di Kecamatan Buleleng. (2) Menguji pengaruh kualitas produk terhadap minat beli produk Lipstik Wardah di Kecamatan Buleleng. (3) Menguji pengaruh kepercayaan merek terhadap minat beli produk Lipstik Wardah di Kecamatan Buleleng.

Hasil penelitian ini diharapkan dapat memberikan manfaat berupa manfaat teoritis dan manfaat praktis. Secara teoritis penelitian ini diharapkan dapat memberikan sumbangan pemikiran dalam pengembangan ilmu pengetahuan pada bidang kajian manajemen pemasaran khususnya yang berkaitan dengan pengaruh kualitas produk dan kepercayaan merek terhadap minat beli. Secara praktis hasil penelitian ini dapat memberikan gambaran mengenai kualitas produk dan kepercayaan merek terhadap minat beli, sehingga dapat dijadikan masukan yang berguna bagi para pelaku pasar terutama produsen produk kosmetik Wardah. 
Secara teoritik penelitian ini dilandasi beberapa teori tentang minat beli, kualitas produk, dan kepercayaan merek. Menurut Semuel \& Suryanata (2017), minat beli merupakan perilaku konsumen yang menunjukkan perasaan tertarik dalam membeli suatu produk, berdasarkan pada pengalamannya dalam memilih, menggunakan serta mengkonsumsi suatu produk tersebut. Febriani et al. (2018), menyatakan bahwa minat beli sebagai suatu perasaan yang muncul dengan sendirinya sebagai akibat dari adanya rangsangan yang diterima konsumen dari produk yang dilihatnya sehingga menumbuhkan rasa ketertarikan untuk membeli dan memilikinya. Minat beli merupakan keinginan dalam diri konsumen terhadap suatu produk sebagai dampak dari suatu proses pengamatan dan pembelajaran (Alvin A \& Hidayat, 2018). Dari beberapa definisi di atas dapat disimpulkan bahwa, minat beli merupakan suatu rangsangan dalam diri konsumen pada suatu produk yang dilihat sebelumnya dan berhubungan dengan tindakan pembelian akibat adanya berbagai proses evaluasi sebelumnya terhadap suatu produk. Menurut Ridwanudin \& Fanni (2019), minat pembelian dapat diukur dengan berbagai dimensi. Secara umum dimensi tersebut adalah berkenaan dengan empat dimensi pokok, yaitu : (1) Minat Transaksional merupakan kecendrungan konsumen untuk selalu membeli produk (barang dan jasa) yang dihasilkan perusahaan yang didasarkan pada rasa kepercayaan yang tinggi terhadap perusahaan tersebut. (2) Minat Referensial merupakan kecendrungan konsumen untuk mereferensikan produknya kepada orang lain. Minat tersebut muncul setelah konsumen memiliki pengalaman dan informasi mengenai produk tersebut. (3) Minat Preferensial merupakan minat yang menggambarkan perilaku konsumen yang memiliki preferensi utama terhadap produkproduk tersebut. (4) Minat Eksploratif merupakan minat yang menggambarkan perilaku konsumen yang selalu mencari informasi mengenai produk yang di minatinya untuk mengetahui sifat-sifat dari produk tersebut. Menurut (Fakhru et al. (2014), terdapat indikator-indikator dari minat beli sebagai berikut. (1) Attention, merupakan bentuk perhatian konsumen terhadap produk yang ditawarkan oleh produsen. (2) Interest, merupakan rasa ketertarikan konsumen terhadap produk yang ditawarkan oleh produsen. (3) Desire, merupakan keinginan dalam diri konsumen untuk memiliki produk yang ditawarkan oleh produsen. (4) Action, merupakan suatu tindakan konsumen berdasarkan dari berbagai informasi yang diperolehnya serta dan dari mempelajari merek-merek yang bersaing serta fitur dari merek tersebut yang selanjutnya akan melakukan evaluasi dan mempertimbangkan membeli suatu produk.

Kualitas produk merupakan senjata bagi perusahaan yang dapat digunakan di dalam memenangkan persaingan, karena dengan memberikan produk yang berkualitas maka kepuasan konsumen akan tercapai. P Kotler \& Amstrong (2012) mendefinisikan kualitas produk adalah kemampuan sebuah produk dalam memperagakan fungsinya, hal ini termasuk keseluruhan durabilitas, reliabilitas, ketepatan, kemudahan penggunaan, dan juga atribut produk lainnya. Sehingga dalam melakukan pembelian, konsumen akan melihat bagaimana kualitas dari suatu produk yang diharapkannya. Menurut Citra \& Suryono (2016), kualitas produk adalah keseluruhan karakteristik produk yang dihasilkan dari pemasaran, rekayasa, produksi dan pemeliharaan sampai akhirnya produk tersebut dapat digunakan memenuhi harapan pelanggan atau konsumen. Dari pengertian beberapa para ahli dapat disimpulkan bahwa kualitas produk adalah kemampuan dari sebuah produk dalam menjalankan fungsinya, serta tingkat penilaian kemampuan suatu produk yang akan mempengaruhi konsumen terhadap tindakan pembelian. Menurut Kresnamurti \& Arian (2012) menjelaskan bahwa terdapat sembilan dimensi kualitas produk yang membedakan suatu produk dengan lainnya yaitu. (1) Bentuk (Form), (2) Ciri-ciri produk (Features), (3) Kinerja (Performance), (4) Ketepatan (Conformance), (5) Ketahanan (Durabillity), (6) Kehandalan (Reliabillity), (7) Kemudahan perbaikan (Repairabillity), (8) Gaya (Style), (9) Desain (Design). Terdapat enam indikator yang dapat digunakan untuk mengukur kualitas produk yaitu: 1) Kinerja (Performance), 2) Daya tahan (Durability), 3) Ciri-ciri produk (Features), 4) Kesesuaian 
dengan spesifikasi (Conformance to specification), 5) Kehandalan (Reliability) (Susanti, 2017).

Menurut Mulyadi, Dkk (2015), munculnya rasa kepercayaan pada suatu disebabkan adanya harapan bahwa pihak lain akan bertindak sesuai dengan kebutuhan dan keinginan konsumen dalam merencanakan pembelian terhadap sejumlah merek. Ketika seseorang telah mempercayai pihak lain maka mereka akan yakin bahwa harapan mereka akan terpenuhi dan tidak akan ada kekecewaan Ryan (dalam Arista \& Sri, 2011). Menurut Dewi (2017), menyatakan bahwa kepercayaan merek merupakan bentuk persepsi akan keterhandalan suatu merek tertentu yang dilihat dari sudut pandang konsumen yang diikuti dengan kesediaan untuk mempercayai hal yang berhubungan dengan merek tersebut. Dari pengertian beberapa ahli tersebut dapat disimpulkan bahwa kepercayaan merek merupakan harapan konsumen terhadap suatu merek yang dengan keyakinan bahwa merek tersebut tidak akan mengecewakan dengan melihat dari kehandalan suatu merek. Menurut Kustini Dkk (2011), diuraikan secara singkat masing-masing dimensi kepercayaan merek yaitu: 1. Keterandalan merek dalam memenuhi janjinya (reliability), 2. Kemampuan merek untuk menciptakan minat dan niat untuk membeli (intentionally). Terdapat indikator kepercayaan merek, yaitu: (1) Brand characteristics mempunyai peran yang sangat penting dalam menentukan pengambilan keputusan konsumen untuk mempercayai suatu merek yang menyangkut tentang kinerja merek yang dapat diramalkan, mempunyai reputasi dan kompetensi merek. (2) Company characteristics dalam suatu merek juga dapat mempengaruhi tingkat kepercayaan konsumen pada merek tersebut. Consumer brand characteristics merupakan dua kelompok (konsumen dan merek) yang dapat saling mempengaruhi kepercayaan merek meliputi, kemiripan antara konsep emosional konsumen dengan kepribadian merek, kesukaan, dan pengalaman terhadap merek (Agustina et al., 2018).

\section{METODE}

Penelitian ini menggunakan desain kuantitatif kausal. Menurut Sugiyono (2010) penelitian kuantitatif merupakan penelitian yang digunakan untuk meneliti populasi atau sampel tertentu dengan pengumpulan data menggunakan instrumen penelitian dan analisis data bersifat statistik dengan tujuan untuk menguji hipotesis. Adapun langkahlangkah yang terdiri dari a) rumusan masalah, b) mengkaji teori, c) merumuskan hipotesis, d) mengumpulkan data, e) mengolah data, dan f) menarik kesimpulan. Metode pengumpulan data yang digunakan dalam penelitian ini menggunakan metode kuesioner. Penelitian ini dilakukan untuk mengetahui pengaruh kualitas produk dan kepercayaan merek terhadap minat beli produk Lipstik Wardah di Kecamatan Buleleng. Terdapat tiga variabel yang akan diteliti dalam penelitian ini, yaitu kualitas produk $\left(X_{1}\right)$ dan kepercayaan merek $\left(X_{2}\right)$ sebagai variabel bebas dan minat beli $(Y)$ sebagai variabel terikat. Metode analisis yang digunakan adalah analisis regresi linier berganda. Penelitian ini menggunakan penelitian sampel. Menurut Sugiyono (2010) menyatakan bahwa sampel merupakan suatu bagian dari jumlah dan karakteristik yang dimiliki oleh suatu populasi. Banyaknya sampel dalam penelitian tergantung dari jumlah prameter yang diestimasi. Pedomannya adalah 5-10 kali jumlah parameter yang diestimasi, jumlah sampel adalah 5-10 dikali jumlah indikator (Ferdinand, 2013). Dalam penelitian ini menggunakan 12 indikator. Sehingga minimal sampel yang bisa diambil dalam penelitian ini adalah $12 \times 5=60$ sampel minimal dan maksimal sampel yang bisa diambil dalam penelitian ini adalah $12 \times 10=$ 120. Pada penelitian ini menggunakan sampel sebanyak 100 responden. Teknik penentuan sampel yang digunakan dalam penelitian ini adalah dengan menggunakan teknik purposive sampling. Menurut Sugiyono (2010) purposive sampling merupakan metode penentuan sampel dengan beberapa pertimbangan atau tujuan tertentu. Adapun kriteria responden yang diambil sebagai sampel adalah: (1) Konsumen produk Lipstik Wardah di Kecamatan Buleleng yang pernah membeli dan atau menggunakan produk Lipstik Wardah. (2) Responden wanita yang 
berumur 17-45 tahun. Pemilihan berdasarkan usia tersebut dianggap telah dewasa dan mampu menjawab pertanyaan yang diajukan oleh peneliti.

\section{HASIL DAN PEMBAHASAN}

Hasil analisis regresi linier berganda dengan mengggunakan bantuan program aplikasi komputer Statistical Package for Social Science (SPSS) 22 for Windows, maka diperoleh hasil penelitian pengaruh masing-masing variabel kualitas produk dan kepercayaan merek terhadap keputusan minat beli produk Lipstik Wardah di Kecamatan Buleleng dapat digambarkan pada gambar 1 berikut.

$$
\varepsilon=0,292
$$

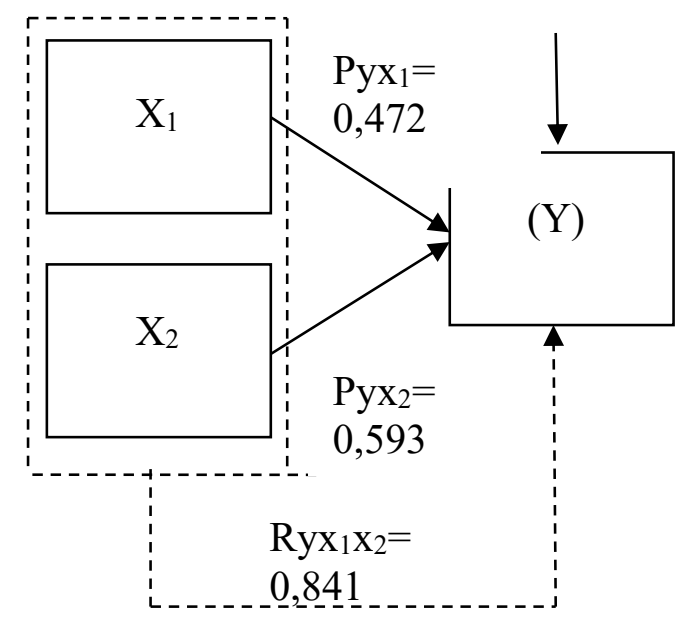

Gambar 1. Struktur Pengaruh Variabel
$X_{1}$ dan $X_{2}$ terhadap $Y$

Keterangan : $\mathrm{X}_{1}=$ Kualitas Produk

$\mathrm{X}_{2}=$ Kepercayaan Merek

$Y=$ Minat Beli

$\varepsilon=$ Faktor lain

Besar sumbangan pengaruh variabel $X_{1}$ dan $X_{2}$ terhadap $Y$ dalam penelitian ini dapat dilihat pada Tabel 1 berikut.

Tabel 1. Sumbangan pengaruh variabel $X_{1}$ dan $\mathrm{X}_{2}$ terhadap $\mathrm{Y}$

\begin{tabular}{lcc}
\hline Keterangan & $\begin{array}{c}\text { Besar } \\
\text { Sumbangan }\end{array}$ & Persentase \\
\hline $\begin{array}{l}\text { Pengaruh } \\
\text { langsung } \\
\mathrm{X}_{1} \text { terhadap } \\
\mathrm{Y}\end{array}$ & 0,223 & $22,3 \%$ \\
$\begin{array}{l}\text { Pengaruh } \\
\text { langsung } \\
\mathrm{X}_{2} \text { terhadap }\end{array}$ & 0,352 & $35,2 \%$ \\
$\mathrm{Y}$ & & \\
$\begin{array}{l}\text { Besar } \\
\text { pengaruh }\end{array}$ & 0,708 & $70,8 \%$ \\
$\begin{array}{l}\mathrm{X}_{1} \text { dan } \mathrm{X}_{2} \\
\text { terhadap } \mathrm{Y}\end{array}$ & & \\
$\begin{array}{l}\text { Besar } \\
\text { pengaruh } \\
\text { faktor lain } \\
\text { terhadap } \mathrm{Y}\end{array}$ & 0,292 & $29,2 \%$ \\
\hline \multicolumn{1}{c}{ Total } & 1,000 & $100,00 \%$ \\
\hline
\end{tabular}

Sumber: Pengolahan data SPSS

Berdasarkan rekapan hasil uji regresi berganda pada Tabel 1 menunjukan kualitas produk dan kepercayaan merek berpengaruh signifikan terhadap minat beli dengan p-value 0,000 < Alpha (a) 0,05 dan sumbangan pengaruh sebesar $70,8 \%$. Hasil tersebut menunjukan bahwa sebesar 70,8\% minat beli dipengaruhi oleh kualitas produk dan kepercayaan merek. Sedangkan pengaruh variabel lain adalah sebesar $29,2 \%$. Hal ini dapat disimpulkan bahwa variabel kualitas produk dan kepercayaan merek secara bersama-sama berperan dalam meningkatkan minat beli. Kajian empirik yang turut mendukung temuan penelitian ini adalah hasil penelitian yang dilakukan oleh Mulyadi, Dkk (2015) yang mengungkapkan bahwa kualitas produk dan kepercayaan merek berpengaruh signifikan terhadap minat beli.

Berdasarkan rekapan hasil uji regresi berganda pada Tabel 1 menunjukan kualitas produk berpengaruh positif dan signifikan terhadap minat beli dengan $p$-value $0,000<$ Alpha (a) 0,05 hal ini menyatakan bahwa menolak $\mathrm{HO}$ dengan sumbangan pengaruh sebesar $22,3 \%$. Hal ini dapat disimpulkan bahwa variabel kualitas produk berperan dalam meningkatkan minat beli. Temuan penelitian ini didukung dengan hasil penelitian yang dilakukan oleh Valentine \& Agus (2019) yang menyatakan bahwa 
kualitas produk berpengaruh positif dan signifikan terhadap minat beli.

Berdasarkan rekapan hasil uji regresi berganda pada Tabel 1 menunjukan kepercayaan merek berpengaru positif dan signifikan terhadap minat beli dengan $p$ value $0,000<$ Alpha (a) 0,05 hal ini menyatakan bahwa menolak $\mathrm{HO}$, dengan sumbangan pengaruh sebesar $35,2 \%$. Hal ini dapat disimpulkan bahwa variabel kepercayaan merek berperan dalam meningkatkan minat beli. Kajian empirik yang mendukung penelitian ini adalah hasil penelitian yang dilakukan oleh Tria, Dkk (2018), yang menyatakan bahwa kepercayaan merek memiliki pengaruh signifikan terhadap minat beli konsumen.

\section{SIMPULAN DAN SARAN}

Berdasarkan hasil dan pembahasan yang dilakukan, maka dapat ditarik kesimpulan sebagai berikut: (1) Kualitas produk dan kepercayaan merek berpengaruh signifikan terhadap minat beli produk Lipstik Wardah di Kecamatan Buleleng. (2) Kualitas produk berpengaruh positif dan signifikan terhadap minat beli produk Lipstik Wardah di Kecamatan Buleleng. (3) Kepercayaan merek berpengaruh positif dan signifikan terhadap minat beli produk Lipstik Wardah di Kecamatan Buleleng.

Berdasarkan hasil, pembahasan, dan simpulan, maka dapat diajukan beberapa saran sebagai berikut. (1) Bagi peneliti selanjutnya yang tertarik untuk mengkaji aspek yang serupa diharapkan dapat mengembangkan penelitian ini dengan menambahkan variabel-variabel lain yang mempengaruhi minat beli, mengembangkan subjek penelitian dan dapat memperbanyak teori-teori tentang variabel yang digunakan serta dapat menggunakan teknik analisis data yang lain agar dapat menjadi acuan dari penelitian-penelitian selanjutnya dan dapat menambah ilmu pengetahuan khusunya dalam manajemen pemasaran. (2) Bagi Wardah, diharapkan agar memperhatikan kualitas produk dan menjaga kepercayaan merek konsumen dalam upaya untuk meningkatkan minat beli, karena penelitian ini membuktikan bahwa kualitas produk dan kepercayaan merek dapat mempengaruhi minat beli. Hal tersebut karena kualitas produk dan kepercayaan merek bertujuan untuk meningkatkan rasa kepuasan dan kepercayaan konsumen, sehingga akan mendukung terciptanya minat beli yang tinggi.

\section{DAFTAR PUSTAKA}

Afianka, M. (2012). Pengaruh Brand Image terhadap Minat Beli Konsumen. Skripsi: Universitas Indonesia.

Agustina, Nadia, \& Dkk. (2018). Pengaruh Kepuasan Pelanggan, Biaya Beralih, dan Kepercayaan Merek terhadap Loyalitas Pelanggan (Survei pada Pengguna Kartu Operator Seluler Simpati pada Mahasiswa Jurusan IImu Administrasi Bisnis Angkatan 2015/2016 dan 2016/2017 Fakultas IImu Administrasi. Jurnal Administrasi Bisnis (JAB), 64(1), 1-10.

Alkutubi, M., \& Muhammad. (2019). Pengaruh Kualitas Produk, Citra Merek dan Kepercayaan Merek terhadap Minat Beli Layanan Internet Telkom Indihome di Kota Yoyakarta. Skripsi: Universitas Ahmad Dahlan.

Alvin A, B., \& Hidayat, A. (2018). Pengaruh Citra Merek dan Kualitas Produk terhadap Minat Beli Snack Coklat Tobelo pada PT. Bumi Tangerang Coklat Utama. ECo-Buss Jurnal, 1(112).

Arista, D., \& Sri, R. (2011). Analisis Pengaruh Iklan, dan Citra Merek terhadap Minat Beli Konsumen. Aset, 13(1), 37-45.

Bagus, D. R. (2015). Pengaruh Persepsi Kualitas, Nilai yang Dirasa, Kepercayaan pada Merek dan Citra Merek terhadap Niat Beli Kamera Digital Sony di Kota Sidoarjo. Tugas Akhir: STIE PERBANAS Surabaya.

Bastian, C. W. (2019). Sejarah Berdirinya PT Paragon Technology and Inovation Hingga Sukses. https://www.idntimes.com/life/career/ch rist-bastian-waruwu/sejarah-ptparagon-c1c2/4

BPOM. (2019). Statistic Produk Yang Mendapat Persetujuan Izin Edar. www.pom.go.id.

BPS. (2020). Proyeksi Penduduk Kabupaten Buleleng Menurut Jenis Kelamin, 20102020. https://bulelengkab.bps.go.id/ 
Candra, A.P, H., Dkk. (2014). Pengaruh Citra Merek, Kualitas Produk Terhadap Kepercayaan serta Keputusan Pembelian (Survei pada Pembeli Sepeda Motor Honda Vario pada PT Sumber Purnama Sakti di Kabupaten Gresik). Jurnal Administrasi Bisnis (JAB), 15(2), 1-6.

Citra, T., \& Suryono. (2016). ). Analisis Pengaruh Kualitas Produk dan Citra Merek terhadap Keputusan Pembelian Cetakan Continuous Form melalui Kepercayaan Merek (Studi pada Percetakan Jadi Jaya Group, Semarang). ECo-Buss Jurnal, 5(2), 112.

Deniel, P., Dkk. (2018). The Influence of Product Quality on Purchase Intention Through Electronic Words of Mouth in PT. Telkomsel Medan. The International Conference of Organizational Innovation, 1-9.

Dewi, M. (2017). Pengaruh Kepercayaan Merek terhadap Loyalitas Konsumen pada Produk Kosmetik Pixy (Studi Kasus pada Mahasiswi Universitas Samudra). Jurnal Manajemen Dan Keuangan, 6(2), 1-11.

Fakhru, N, M. R., \& Yasin, H. (2014). Pengaruh Promosi dan Harga terhadap Minat Beli Perumahan Obama $\mathrm{Pt}$. Nailah Adi Kurnia Sei Mencirim Medan. Jurnal Manajemen \& Bisnis, 4(2), 1-9.

Fandiyanto, Randika, \& Ratih, E. K. (2019). Pengaruh Kepercayaan Merek dan Citra Merek terhadap Minat Beli Ulang "Kopi Toraja" Di Coffee Josh Situbondo. Jurnal IImiah IImu Ekonomi Dan Bisnis, 1(2), 1-22.

Febriani, Nufian, S., \& A, W. W. (2018). Teori dan Praktis: Riset Komunikasi Pemasaran Terpadu. Malang: UB Press.

Ferdinand, A. (2013). Metode Penelitian Manajemen. Semarang: Penerbit Universitas Diponegoro.

GBGI. (2018). Indonesia's Cosmetic Industry.

http://www.gbgindonesia.com/en/manu facturing/article/2018/indonesia_s_cos metics_industry_the_rise_of_halal_cos metics_11842.php

Hudzaifah. (2018). Analisis Pengaruh Kualitas Produk dan Kepercayaan
Merek terhadap Minat Beli Ulang yang Dimediasi oleh Kepuasan Konsumen (Studi Kasus pada Konsumen Samsung Smartphone di Undip). Semarang: Universitas Diponegoro.

Hulu, P., \& Ruswanti, E. (2018). Influence of Product Quality, Promotion, Brand Image, Cunsomer Trust towards Purchase Intention (Studi Case On Pocari Sweat Isotonic Drink In Indonesia ). Journal of Business and Management, 20(8), 55-61.

Iwan, Dkk. (2019). Analisis Kualitas Produk terhadap Minat Beli dan Dampaknya Pada Keputusan Pembelian Produk Oriflame. Jurnal Manajemen Dan Bisnis, 3(3), 1-6.

Kotler, P, \& Amstrong, G. (2012). Principles of Marketing Edisi $14 . \quad$ England: Pearson Education Limited.

Kotler, Philip, \& Keller, K. L. (2016). Marketing Management Edisi 15. Global Edition. United kingdom: Pearson Education.

Kresnamurti, R., \& Arian, P. (2012). Pengaruh Kualitas Produk dan Citra Merek terhadap Loyalitas Konsumen pada Produk Oli Federal di Wilayah Jakarta Timur. Jurnal Sains Ekonomi, 10(1), 1-14.

Kustini, Dkk. (2011). Experiental Marketing, Emotional Branding, and Brand Trust and their Effect on Loyalty on Honda Motorcycle Product. Journal of Economics, Business, and Accountancy Ventur, 14(1), 19-28.

Mulyadi, Dkk. (2015). Analisis Pengaruh Iklan, Kepercayaan Merek dan Kualitas Produk terhadap Minat Beli (Studi pada Konsumen Mie Sedap di Pasar Pedurungan Kidul Semarang). Journal of Management, 1(1), 1-7.

Panglipurningrum, S., Yofhi, Dkk. (2018). Pengaruh Kualitas Produk Dan Harga terhadap Minat Beli Konsumen yang di Mediasi oleh Brand Image dan Brand Trust (Studi pada Konsumen Tenun lkat "Arimbi" Kabupaten Sragen). Buletin Ekonomi, 16(1), 1-136.

Philius, Mamahit, Dkk. (2015). Pengaruh Brand Image, Brand Trust, dan Kualitas Produk terhadap Keputusan Pembelian Mobil Toyota All New Yaris pada Pt. Hasjrat Abadi Manado. Jurnal Berkala 
IImiah Efisiensi, 15(5), 1-11.

87-96.

Pramuda, \& Hafizha, W. (2010). Analisis

Pengaruh Ketidakpuasan Konsumen, Kebutuhan Mencari Variasi Produk, Harga Produk dan Iklan Produk Pesaing terhadap Keputusan Perpindahan Merek dari Sabun Pembersih Wajah Biore. Semarang: Diponegoro.

Ridwanudin, R., \& Fanni, H. H. (2019). Pengaruh Brand Image dan Brand Trust terhadap Minat Beli Konsumen Daihatsu Grand New Xenia Di Bandung. Jurnal E-Proceeding of Applied Science, 5(2), 1-10.

Semuel, H., \& Suryanata, A. (2017). Analisis Ewom, Brand Image, Brand Trust dan Minat Beli Produk Smartphone di Surabaya. Jurnal Manajemen Pemasaran, 8(2), 1-8.

Sigit, A. S. (2018). Kinerja Industri Kosmetik Nasional Lampaui Pertumbuhan Ekonomi. https://kemenperin.go.id/artikel/19435/ Kinerja-Industri-Kosmetik-NasionalLampaui-Pertumbuhan-Ekonomi

Sugiyono. (2010). Metode Penelitian Bisnis (Pendekatan Kuantitatif, Kualitatif, dan R\&D). Bandung: CV. Alfabeta.

Susanti, D. (2017). Pengaruh Kualitas Produk terhadap Minat Beli Konsumen dalam Membeli Produk Tupperware pada Perumahan Griya Tika Utama Pekanbaru. Jurnal Fakultas Ekonomi UMSB, 3(5), 1-10.

Tria, N., \& Dkk. (2018). Pengaruh Kesadaran Merek, Kepercayaan Merek dan Keunggulan Produk terhadap Minat Beli Produk Luxuri Fashion Brand dengan Gender sebagai Moderating pada Pemasaran Media Sosial di Kota Banda Aceh. Jurnal Magister Manajemen Fakultas Ekonomi Dan Bisnis Unsyiah, 2(1), 1-16.

Valentine, C., \& Agus, M. (2019). Pengaruh Citra Merek dan Kualitas Produk terhadap Minat Beli Iphone di Bandung. E-Proceeding of Applied Science, 5, 18.

Wirayanthy, N., \& Singgih, S. (2019). Pengaruh Harga, Citra Merek dan Kualitas terhadap Minat Beli Produk Private Label. JMD: Jurnal Riset Manajemen \& Bisnis Dewantara, 2(1), 